\title{
An integrated approach by fmea \& fuzzy prioritization method at pharmaceutical industry quality control
}

\author{
G. Nilay YÜCENUR ${ }^{1 *}$ (D), Seren ÇATALTEPE ${ }^{1}$ (D) Irem SAKIN ${ }^{1}$ (iD) \\ ${ }^{1}$ Department of Industrial Engineering, Faculty of Engineering and Architecture, Beykent, 34398 Istanbul, Turkey
}

\begin{abstract}
Protecting public health, taking preventive measures and ensuring recovery in case of any disease are conditions for creating a healthy life. In order to create this life, the manufacturing process of the pharmaceutical industry needs to be formed carefully. In this study there is a risk analysis application into operational processes of a pharmaceutical company. In application study, operational processes of sample company were examined and analyzed from October to May. Within the scope of the study, a two-stage approach was proposed in the analysis of the data obtained. In the first phase, fishbone analysis was carried out to determine the risks in the operational processes and the potential risks in two separate production lines were determined. In the second stage, the risk prioritization method was used and risk priority numbers (RPN) were calculated for all risks. In all these analysis, more realistic and valid results were obtained with the usage of fuzzy logic and the calculations of RPNs were made more objective and independent from analysts. After the determination of RPNs, precautions were suggested for high risky failures. Following the implementation of precautions, new RPNs were calculated for all failures. The old and the new RPNs were compared for all risky failures and all precautions were examined with their impacts on the process. As a result, all examined failures' risk prioritization numbers were reduced in the ratio between $72 \%$ and $90 \%$, the operational processes were improved.
\end{abstract}

\section{Article info \\ History:}

Received:19.05.2019

Accepted:18.10.2019

Keywords:

Failure mode and

effect analysis,

Fuzzy prioritization

method,

Pharmaceutical sector,

Risk Analysis.

\section{Introduction}

Today companies have to increase their market share and they effort to reduce costs in an increasingly competitive environment. The competition to be continuous, it must be efficient and accurate production. In the factory working conditions, the desired quality and at a certain time to reveal the cost of the desired products are not easy. In this way, firms have to increase their market share and satisfied customers.

Quality can be under defined conditions and within a defined period of time able to carry out the required functions. Quality, along with changing technologies and conditions, it is a constantly evolving concept. This development goes in line with consumer needs. Product must be taken under the quality assurance during the production stages. However, the product quality to measure all properties is not possible in terms of both cost and time. Therefore, various methods are used to determine the important quality characteristics. These methods occur with a low failure rate and low-cost products.

Providing this situation has led to the emergence of the quality control system. Typically, faults in the quality control system, it is trying to catch after the creation of the product. This situation increases costs. In the newly developed quality system, failures are caught before the creation of the design of the product. Thus, the number of defective products and the cost will be reduced.

To ensure that more easily adapt to changing business conditions and critical performance measures used to ensure quality consistency. In this way, the company is evaluated periodically and improvement work is done. With improvements in risk assessment methods, measures are taken to reduce the risk to a minimum. These measures are ranked in order of priority and evaluated. The purpose of the risk assessment is determining the measures to be taken against failures. In this case, failures are determined in advance and occurrence is minimized. 
Failure mode and effects analysis (FMEA) works by analyzing all the failures that may occur during processing and service of a product, these failures are a set of prevention activities. The goal is to eliminate failures that may occur in the production phase determining in advance. As a result of this objective, determining possible failures and their causes, preventive measures are taken. Thus, the customer would have offered zero-defect products.

In literature there are lots of studies about FMEA in different research fields. Especially, in recent years the linguistic variables and fuzzy logic have been applied in FMEA method. For example Carpitella et al. (2018) and Kutlu and Ekmekçioğlu (2012) used fuzzy TOPSIS based fuzzy AHP, Fattahi and Khalilzadeh (2018) applied the extended MULTIMOORA and AHP under fuzzy environment to the risk evaluation, Kumru and Kumru (2013) applied fuzzy FMEA to improve purchasing process in a public hospital, Mandal and Maiti (2014) proposed fuzzy similarity value and possibility theory-based approach for risk analysis, Chen et al. (2014) used a structural model based on the FMEA and fuzzy fault tree for a risk assessment of an oxygen-enhanced combustor, Chanamool and Naenna (2016) applied fuzzy FMEA to improve decision making process in an emergency department in hospitals, Dağsuyu et al. (2016) used classical and fuzzy FMEA in a sterilization unit's risk analysis, Tooranloo and Ayatollah (2016) proposed a model for FMEA based on intuitionistic fuzzy approach and Adar et al. (2017) analyzed risk by FMEA and Fuzzy FMEA of supercritical water gasification system used in the sewage sludge treatment [1-10].

In spite of all these papers there are few papers about FMEA and pharmaceutical industry such as Lv and Liang (2014), Bhattacharya (2015) and Hajimolaali and Asl (2016) [11-13]. These papers are very valuable studies about FMEA and risk management in pharmaceutical industry. On the other hand, Su et al. (2012) adopted FMEA to improve the blood transfusion processes in healthcare sector [14].

On the other hand some researchers studied with extended VIKOR method and FMEA in their papers. For example, Liu et al. (2012) used FMEA with extended VIKOR method under fuzzy environment in risk evaluation, Liu et al. (2015) applied combination weighting and fuzzy VIKOR method to FMEA and Mohsen and Fereshteh (2017) used the extended VIKOR method based on entropy measure for the failure modes risk assessment [15-17].
In literature, there are few papers about our application methods. Such as Mikhailov and Tsvetinov (2004)'s paper is the fundamental of fuzzy prioritization approach, Özfirat (2014)'s paper about a new risk analysis methodology integrating fuzzy prioritization method and FMEA and Rahimi et al. (2016)'s paper about prioritization of failures in radiation therapy delivery [18-20]. Even if both papers used fuzzy prioritization methods for FMEA's first step, they are different from our paper about application field.

After the literature review, it is clear that this paper is the first study about risk assessment analysis with FMEA method and fuzzy prioritization in a pharmaceutical industry. Our case study focuses on our sample company, which is a part of Turkey pharmaceutical sector. We examined our company's risk analysis by FMEA method under fuzzy environment.

This paper is aimed to analyze the risk assessment of failures in our sample company's solid (blister) and liquid (syrup) operation lines. We determined the risks with linguistic variables under fuzzy environment then suggested precautions for minimizing risk levels of high risk failures.

In this study, fuzzy AHP method is used to prioritization the FMEA values with generating pairwise matrixes. Briefly, after all literature review there are two main objectives:

- Proposing a risk assessment method using fuzzy logic in FMEA

- Being the first study in literature, because of using fuzzy prioritization method for risk assessment step of FMEA in a new research area such as pharmaceutical sector.

As an outline, Section 2 includes quality and risk assessment and its methods in pharmaceutical sector. Traditional FMEA method, its purpose, benefits, types and implementation steps are in Section 3. Section 4 explains triangular numbers for fuzzy prioritization method in FMEA. Section 5 includes application part with identifying risks, examining the risks with fuzzy comparison matrixes, weighting importance coefficients, converting them to FMEA degrees, calculating RPN numbers, suggesting precautions and calculating new RPN numbers. Finally, concluding remarks and suggestions for further studies are given in Section 6. 


\section{Quality and Risk Assessment in Pharmaceutical Sector}

Nowadays, with the development of technology and globalization rather a competitive environment is strengthened. There are many tasks to companies in order to survive in this competitive environment. One of them is to uncover a quality product. Quality products to best meet customer requirements. This location should always follow market companies.

The concept of quality has evolved and changed from the old year to the present day. There is no fixed definition. We may face many definitions related to quality. The reason for this is the differences in people's quality perspective. Quality is a proportional relation with customer expectations. If it means a quality brand for a person the other person can mean monetary value. Thus, quality has become a multidimensional concept.

Today, companies are continuing their existence and use of risk assessment techniques to ensure long-term success. Physical, chemical, biological, ergonomic and other hazards are identified dangers that can occur from them. It is considered to be likely to cause risky situations.

\subsection{Risk assessment processes in pharmaceutical sector}

Today has the largest research and development potential in a global industry because of the risks associated with human life. In line drug policies, both quality and the delivery of medication to the patient in the best economic conditions is the main target. However, in production processes and due to some unusual circumstances that occurred during distribution serious risks can be occurred. Drugs sourced from the treatment of 1.3 million people today suffer and are died 1 person per day. The pharmaceutical industry should be examined carefully serious risk accommodates every stage of production. As a result of a failure to collect any products from the market, it cannot prevent damage caused by people arriving.

\subsection{GMP (good manufacturing practices) in pharmaceutical sector}

The risk of entanglement of products and services should be preventive measures. For each production stage, different criteria and production location, environment, equipment, special raw materials are available for specific applications. These applications are collected under the name as GMP (Good Manufacturing Practices). GMP is a quality risk approach for applying to minimize risks and if possible for eliminating them. Pharmaceutical production performed by these rules, provided that the healthiest way to reach the patient. Drugs' scientific and technological quality and desired qualifications should be prepared with certain applications. Check the validity of this application and the results are performed for process validation. Validation often used in the pharmaceutical industry, it means to prove the validity of the entire production process. The products produced in standard determined whether control is performed [21].

The purpose of GMP is equipment cleaning and ventilation housekeeping, dual signature use of raw materials by introducing read the barcode, to comply with labeling rules and pay attention to the labeling of raw materials, intermediate labeling of any point in the flow chart, to avoid failures that can occur in the packing section.

In risk assessment, the risks are analyzed and graded to decide whether to tolerate risk, if it cannot tolerate taking necessary precautions to minimize. For risk assessment process firstly the data is collected, the hazards are identified, the sources of hazards are examined and with precautions the hazards are eliminated. In risk assessment methods, assessment varies according to the environment and expectations. In literature there are more than 150 risk assessment methods and standards. FMEA is one of the most popular quality control and risk assessment method.

In FMEA, the product or process is determined before the emergence of failures that can occur and the analysis methods is necessary for measurements.

\section{Failure Mode and Effects Analysis (FMEA)}

Changing competitive environment within the company's service and in the time until it reaches the customer from the design of their products, they encounter failures. Based on these failures is located in the human factor. These failures make the company become an inefficient and lose customer satisfaction [22].

In other respects, mistakes can hurt financially, spiritually also can lead to serious damage. For example, death is the result of failure, shows the way to the bankruptcy of the company. 
When we examine this situation, receiving and resolving action before failures occur, it will increase customer satisfaction. The failure occurred during the production phase will be done at that time will be needed to reduce costs will occur in the future.

Today, customer expectations are constantly evolving. Due to these evolving expectations the companies have not any chance to make a mistake in product or process. So before bringing out a new product, the companies should minimize the risks of mistakes. At this stage, FMEA will help to companies. In the usage of this analysis, the risk of failures will be destroyed and customer expectations will be the best as opposed to.

A correctly applied FMEA, the practitioner system, design, process, and service provides useful information that will allow you to reduce the risks. Therefore, this analysis is a technique for reliability assurance.

FMEA is a powerful risk assessment method. The method examines risks by using qualitative and quantitative data. In short, FMEA technique assess the possible risks that may occur in design, production and services steps of companies and it can help them for reducing or eliminating these risks.

FMEA aims to identify risks in advance is taking precautions. This aim is realized when it increases the competitiveness of companies. Additionally, the minimum risk decreases the cost of failure, providing the quality and reliability of the increase. So, FMEA has been recently used for a preferred method.

The purpose of FMEA is ensuring the resulting product meets the needs of the customer, analyzing the properties of the product of the design phase, finding the causes and effects of the failures, determining the types of failures and taking regulatory measures to eliminate them $[23,24]$.

Successful FMEA will bring positive results. The most important reason for the application of this analysis is to ensure customer satisfaction. The result of the application for the company is quality and development increases.

FMEA, increases customer satisfaction, minimizes costs, improves product's quality and the competitiveness of the company and also increases job security. These benefits are for the customers, employees and companies. On the other hand FMEA has benefits for the process. It reveals failures, ensures timely production, allows recovery of missing the point, prevents the repetition of failures, provides for the reduction of scrap and waste and helps eliminate unnecessary time.

FMEA is applied when a change is to be made in current products, when new products or new process are developed, in the improvement of processes, in ensuring customer satisfaction, safety and job security, improving the system and in cases where existing product and process failures are detected [25].

\subsection{Types of FMEA}

FMEA can be applied at different stages of the product. The applications are built as hardware for the first time. It is used to determine the failure in the time period. Today it is applied in all kinds of products and services. Depending on the application areas the FMEA types are analyzed in four varieties [22-26-27]:

System FMEA: During the design phase system and sub-systems analysis, FMEA is used for determining the type of failure resulting from system deficiencies. System FMEA aims to provide a balance between the operational factors and economic factors. To achieve this purpose, customer demands and expectations should be considered. The target of this type of FMEA is to improve the quality and reliability of the system.

Design FMEA: Design FMEA is applied before starting production. It examines product failures that will occur because of failures in the design at the manufacturing stage. In short, the determination of all the failures that may arise in the design and properly defined. In design FMEA, there are two opinions. The first one is, generally handled system or product and analyzed down to the smallest part and the second one is started from the smallest parts and advances to the latest state of the system and the product. The selection of opinion depends on the system and the magnitude of the problem.

Process FMEA: Process FMEA is used to examine the manufacturing process. It examines the failure and causes that occur during production. This analysis is used to destroy the types of due to deficiencies in the production and assembly process. All failures do not occur during the production phase, some of them can occur before production. Process FMEA determines the weak points of the production components in the production process such as machine, material, environment and human. 
Service FMEA: Service FMEA helps to analyze products before reaching the customer. In service FMEA, workers, environment, methods, procedures should be in interaction with the material factors. These factors result in the formation individually. Service FMEA is a complex technique. In order to understand the root cause of the failure continuous service should be repeated.

\subsection{Implementation steps of FMEA}

In FMEA, a team is formed where products, production processes or services in the presence of failures, determining the failure risk priorities, the realization of preventive actions for focusing on prevention before reaching the customer. FMEA identifies potential failures and determines the causes and effects of these failures. Necessary observations and studies are done and they can be applied after the proposed reformative actions. The aim is to prevent the products from failures before reaching the customers.

In FMEA implementation firstly the scope of analysis and FMEA team are established. Then the process is examined, failure modes and their causes and impacts are determined. For all failures occurrence, severity and detection values are determined and risk priority number (RPN) is calculated. After suggesting actions and their implementation, new RPN value is calculated [28].

Failure type of internal and external customer needs and does not overlap with the demands and expectations. Failure type of the function of determining, specific criteria such as safety, place, time, method, performance, and cost are taken into consideration due to customer complaint reports, test reports, reliability analysis of the results, related products and system information $[29,30]$.

Determining the failure's criticality levels, occurrence, severity and detection values are calculated. Priority order is determined based on these values. The important thing is to identify mistakes before they happen as early as possible and take measures. Therefore determined value is based on experience and results.

\subsubsection{Determination of occurrence values}

Occurrence is the possibility of the occurrence of possible causes of failures and causing the type of failure during the use of the product. Shows the occurrence of failures and potential failures of each species is related to the possibility of realization.

Occurrence value of FMEA application is not identified as a possibility. There are two different approaches to determining the value of occurrence, the first approach, a failure type (or reason for failure) to determine the value to occurrence and the second approach is what caused the failure value associated with the occurrence of the type of failure has appeared in its results. The occurrence value of the failure is multiplied by these two probability values. The degree of occurrence to determine is based on Wang et al.'s (2009) paper [31].

\subsubsection{Determination of severity values}

The potential results of failure, the consequences case of the realization to evaluate the effects on customers. Damage may bring about the risk of severity seen in the past is determined according to similar situations and the people involved experience. The crisp ratings for severity values are based on Wang et al.'s (2009) paper [31].

\subsubsection{Determination of detection values}

Detection is the degree of failure block access to customers about the availability of existing controls. Possible types of failure, is assumed to occur during the use or the end customer at a later stage, should be passed through the detection measures envisaged. Therefore, the probability values associated with detection, defined as the probability of default, failure to reach customers why they occur.

Detection value is determined by analyzed data from the past and the study benefited from the experience of the team. The Crisp ratings for detection values are based on Wang et al.'s (2009) paper [31].

\subsubsection{Calculation of the rpn values}

Risk priority number (RPN) is a value obtained by multiplying occurrence, severity and detection values as Eq. (1).

$$
\begin{aligned}
& \text { Risk Priority Number }(\text { RPN })=\text { Occurrence }(\mathrm{O}) \\
& \text { x Severity (S) x Detection (D) }
\end{aligned}
$$

RPN is defined and calculated for failures. After this calculation the failures are ranked from small to large due to RPN values. Making reformative actions are started from the largest value after this order. Reformative studies are done on the failure exceeds a 
predetermined threshold value for a number of priority risks [15].

In an evaluation of RPN value: if RPN value is less than 40 then there is no need for precaution, if the value is $40 \leq \mathrm{RPN} \leq 100$ precautions can be taken, if RPN value more than 100 the company must take precautions and suggestions for reducing RPN values [32].

After taking precautions, risk priority number is calculated again with new occurrence, severity and detection values. New RPN is expected to be lower than previous calculations. Drop requested is no specific lower limit, which means a reduction in the number of risk priority if success is achieved. If there is no change in the results, studies should be carried out from the beginning, new FMEA studies should be done to reduce the occurrence and severity to determine value.

\section{Triangular Numbers for Fuzzy Prioritization Method in FMEA}

In this paper, fuzzy numbers are used for prioritization the RPN values as Özfirat (2014)'s study with differences in Analytic Hierarchy Process (AHP) steps [19]. In our proposed model we used Chang's (1996) extent analysis method which is one of the most popular approaches in fuzzy AHP field [33]. The method is used because of its easier calculation steps. Fuzzy AHP is a very useful methodology for important applications in multi-criteria decision making problems under fuzzy environments in recent years [34] and because of human thinking and preferences are inherently imprecise; their vague character can be modelled by fuzzy theory easily [35]. In a method, the decision makers' judgements are treated with pairwise comparisons and the priority vector is found $[36,37]$.

The fuzzy comparison matrixes are used for evaluating the degrees of occurrence, severity and detection with Saaty's scales which is shown in Table 1.

Our proposed method's structure and application steps for prioritizing the risk factors, calculating RPN values under fuzzy environment is given in Fig. 1.

- Identifying risks and fuzzy comparison matrixes for occurrence, severity and detection: According to Özfirat (2014)'s study, firstly the risk factors are identified in FMEA and then fuzzy comparison matrixes are generated for occurrence, severity and detection for all risks.

- Determining importance coefficients (weight vectors) by fuzzy prioritization method: After generating the fuzzy matrixes, fuzzy prioritization method's step is started. For each comparison matrixes, the weight vectors are calculated with Eq. (2), Eq. (3) and Eq. (4) in this step.

$W^{\text {OCCURENCE }}=\left(w_{1}^{O}, w_{2}^{O}, w_{3}^{O}, \ldots, w_{n}^{O}\right)$

$W^{\text {SEVERITY }}=\left(w_{1}^{S}, w_{2}^{S}, w_{3}^{S}, \ldots, w_{n}^{S}\right)$

$W^{\text {DETECTION }}=\left(w_{1}^{D}, w_{2}^{D}, w_{3}^{D}, \ldots, w_{n}^{D}\right)$

$\mathrm{n}$ are the number of risks.

Table 1. Linguistic scale for relative importance [38]

\begin{tabular}{lccc}
\hline \multicolumn{1}{c}{$\begin{array}{c}\text { Linguistic } \\
\text { scales }\end{array}$} & & \multicolumn{2}{c}{ Triangular fuzzy numbers } \\
Number & Conjugate \\
\hline $\begin{array}{l}\text { Equally } \\
\text { important }\end{array}$ & EI & $1,1,1$ & $1,1,1$ \\
$\begin{array}{l}\text { Weakly more } \\
\text { important }\end{array}$ & WI & $2 / 3,1,3 / 2$ & $2 / 3,1,3 / 2$ \\
$\begin{array}{l}\text { Strongly more } \\
\text { important }\end{array}$ & SI & $3 / 2,2,5 / 2$ & $2 / 5,1 / 2,2 / 3$ \\
$\begin{array}{l}\text { Very strongly } \\
\text { more }\end{array}$ & VSI & $5 / 2,3,7 / 2$ & $2 / 7,1 / 3,2 / 5$ \\
$\begin{array}{l}\text { important } \\
\begin{array}{l}\text { Absolutely } \\
\text { important }\end{array}\end{array}$ & AI & $7 / 2,4,9 / 2$ & $2 / 9,1 / 4,2 / 7$ \\
\hline
\end{tabular}

- Converting the importance coefficients (weight vectors) into FMEA degrees: The importance coefficients are the values of the risks occurrence probability according to each other. These values have to be used and converted FMEA degrees by using Wang et al.'s (2009) paper [31]. For this calculation firstly, the risk which has the highest occurrence value is determined by the experts. This occurrence value can be named as $P_{1}$. Then for all risks the occurrence values are calculated as seen in Table 2, D column. Finally, these values are converting to occurrence degrees which are given in Table 2, E column.

The same calculations are made for severity and detection in Table 3-4. 


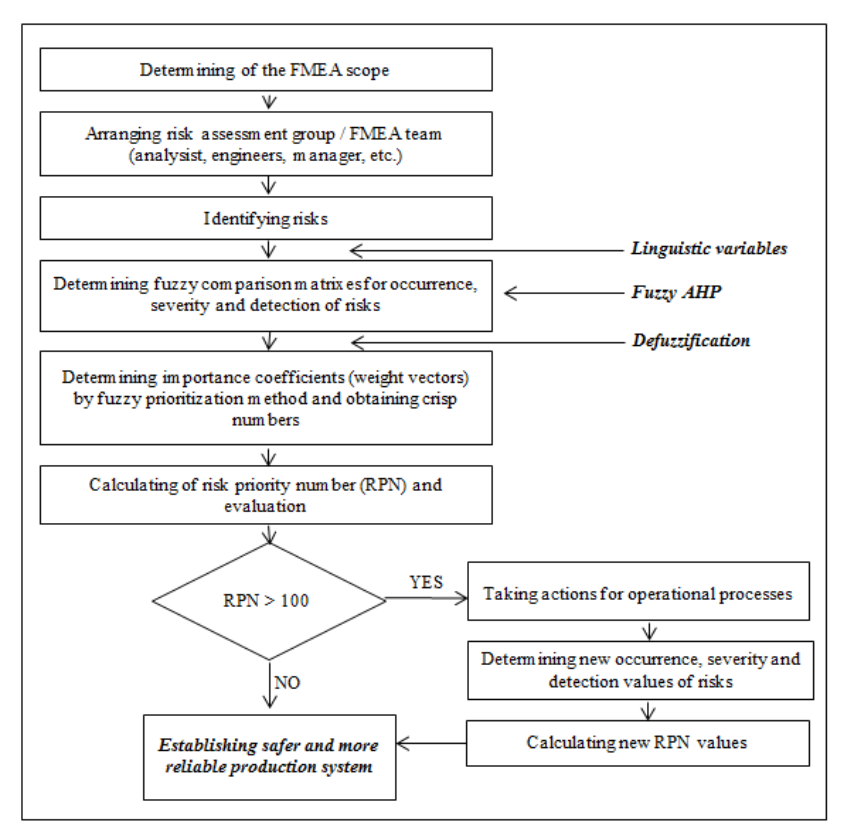

Figure 1. The structure of the proposed method

Table 2. Converting occurrence coefficients found by fuzzy prioritization method into FMEA degrees [19]

\begin{tabular}{|c|c|c|c|c|}
\hline $\mathrm{A}$ & $\mathrm{B}$ & $\mathrm{C}$ & $\mathrm{D}$ & $\mathrm{E}$ \\
\hline $\begin{array}{c}\text { Risk } \\
\text { S }\end{array}$ & $\begin{array}{l}\text { Weight } \\
\text { vector } \\
\text { for } \\
\text { occurrenc } \\
\text { e }\end{array}$ & $\begin{array}{c}\text { Occurrenc } \\
\mathrm{e} \\
\text { (The } \\
\text { highest } \\
\text { value) }\end{array}$ & $\begin{array}{c}\text { Occurrenc } \\
\text { e } \\
\text { by } \\
\text { coefficien } \\
\text { ts }\end{array}$ & $\begin{array}{c}\text { Degree } \\
\text { (Accordin } \\
\text { g to Table } \\
1 \text { ) }\end{array}$ \\
\hline $\mathrm{R}_{1}$ & $\mathrm{w}_{1}^{\mathrm{O}}$ & $\mathrm{P}_{1}$ & - & $\mathrm{O}_{1}$ \\
\hline $\mathrm{R}_{2}$ & $\mathrm{w}_{2}^{O}$ & - & $\mathrm{P}_{1} \cdot\left(\mathrm{w}_{2}^{O}\right.$ & $\mathrm{O}_{2}$ \\
\hline$\ldots$ & $\ldots$ & - & $\left(\mathrm{w}_{1}^{O}\right)$ & $\cdots$ \\
\hline $\mathrm{R}_{\mathrm{n}}$ & $\mathrm{w}_{\mathrm{n}}^{O}$ & - & $\begin{array}{c}\cdots \\
\mathrm{P}_{1} \cdot\left(\mathrm{w}_{\mathrm{n}}^{O}\right. \\
\left./ \mathrm{w}_{1}^{O}\right)\end{array}$ & $\mathrm{O}_{\mathrm{n}}$ \\
\hline
\end{tabular}

Table 3. Converting severity coefficients found by fuzzy prioritization method into FMEA degrees [19]

\begin{tabular}{cccc}
\hline $\mathrm{A}$ & $\mathrm{B}$ & $\mathrm{C}$ & $\mathrm{D}$ \\
\hline Risks & $\begin{array}{c}\text { Weight } \\
\text { vector } \\
\text { for } \\
\text { severity }\end{array}$ & $\begin{array}{c}\text { Severity } \\
\text { (The highest } \\
\text { value, from } \\
\text { Table 2) }\end{array}$ & $\begin{array}{c}\text { Degree by } \\
\text { according to } \\
\text { coefficients }\end{array}$ \\
\hline $\mathrm{R}_{1}$ & $\mathrm{w}_{1}^{S}$ & $\mathrm{~S}_{1}$ & $\mathrm{~S}_{1}$ \\
$\mathrm{R}_{2}$ & $\mathrm{w}_{2}^{S}$ & - & $\mathrm{S}_{1} \cdot\left(\mathrm{w}_{2}^{S} /\right.$ \\
$\ldots$ & $\ldots$ & - & $\left.\mathrm{w}_{1}^{S}\right)$ \\
$\mathrm{R}_{\mathrm{n}}$ & $\mathrm{w}_{\mathrm{n}}^{S}$ & - & $\cdots$ \\
& & & $\mathrm{S}_{1} \cdot\left(\mathrm{w}_{\mathrm{n}}^{S} /\right.$ \\
& & & $\left.\mathrm{w}_{1}^{S}\right)$ \\
\hline
\end{tabular}

Table 4. Converting detection coefficients found by fuzzy prioritization method into FMEA degrees [19]

\begin{tabular}{cccc}
\hline $\mathrm{A}$ & $\mathrm{B}$ & $\mathrm{C}$ & $\mathrm{D}$ \\
\hline Risks & $\begin{array}{c}\text { Weight } \\
\text { vector } \\
\text { for } \\
\text { detection }\end{array}$ & $\begin{array}{c}\text { Detection } \\
\text { (The highest } \\
\text { value, from } \\
\text { Table 3) }\end{array}$ & $\begin{array}{c}\text { Degree by } \\
\text { according to } \\
\text { coefficients }\end{array}$ \\
\hline $\mathrm{R}_{1}$ & $\mathrm{w}_{1}^{D}$ & $\mathrm{D}_{1}$ & $\mathrm{D}_{1}$ \\
$\mathrm{R}_{2}$ & $\mathrm{w}_{2}^{D}$ & - & $\mathrm{D}_{1} \cdot\left(\mathrm{w}_{2}^{D} /\right.$ \\
$\ldots$ & $\ldots$ & - & $\left.\mathrm{w}_{1}^{\mathrm{D}}\right)$ \\
$\mathrm{R}_{\mathrm{n}}$ & $\mathrm{w}_{\mathrm{n}}^{D}$ & - & $\cdots$ \\
& & & $\mathrm{D}_{1} \cdot\left(\mathrm{w}_{\mathrm{n}}^{\mathrm{D}} /\right.$ \\
& & & $\left.\mathrm{w}_{1}^{D}\right)$ \\
\hline
\end{tabular}

- Finding RPN values: For all risks the RPN values are calculated by Eq. (1). If the RPN values are higher than 100 , there must be some proactive and reactive precautions and suggestions.

\section{Applying Fuzzy FMEA in Operation Processes of A Pharmaceutical Company}

The risk assessment is done to review and lists potential failure modes of all blister, bottle, sachet and tube packaging lines used at a sample company which leads to mix-ups and recalls and determines actions for prevention in İstanbul. In the sample company, there are 4 blister lines, 3 bottle lines, 1 tube filling line and 1 sachet filling lines. Our study was performed on the blister and syrup lines. In Fig. 2 there are statistics about headcount of the company and Fig. 3 shows the company's layout plan.

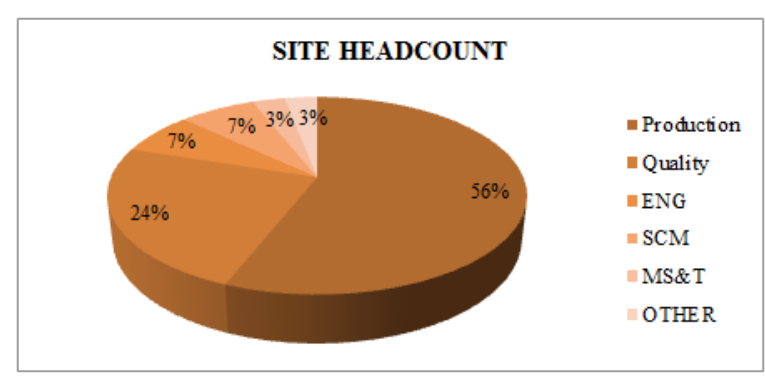

Figure 2. Company statistics

The sample company is a generic pharmaceutical company in all over the world. It has a history of over 120 years and it is a trusted leader who has a reputation for outstanding quality. After the loss of patent protection, quality and affordable medicines development, strategic and customer-oriented approach for manufacturing and marketing has been more important. It now has more than 23,000 employees worldwide in more than 130 countries. It 
has a strong presence on all continents today, equivalent in all major markets are represented in a good way and to patients everywhere, doctors, health service providers and job offers remain close partners.

The company has three production plants in Turkey and also it operates with approximately 1,000 employees. Pharmacy Products is a major actor in the generic pharmaceutical market in Turkey. Since 2005, it has exported huge amount of drugs to 46 different countries.

Products are supplied to many countries such as Turkey, Slovenia, Croatia, Singapore, Ukraine, Australia, Brazil, Russia, Chile, Colombia, Thailand, Macedonia, Hong Kong, Taiwan, the Philippines, and Japan.

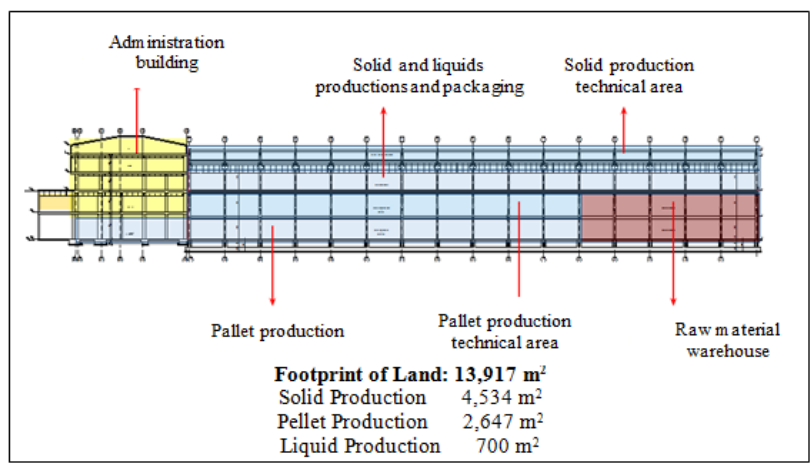

Figure 3. The company plan

\subsection{The purpose of application}

Human health has great importance in today's growing conditions. Because of this important pharmaceutical companies have a mission for protecting human health. In this case, pharmaceutical companies from product design phase until it reaches the customer in time, costeffective, should produce fast and faultless. For this purpose, FMEA is a more suitable risk assessment method for examining the common technical failures which are expected and reducing their effects to a minimum.

In company, there are significant risks in the factory, for example mixing in the packaging line may cause many failures. That's why the FMEA application was done in packaging department of company for examining the system and reducing potential risks.

The application is done in solid (blister) and liquid (syrup) packaging lines for preventing occurred operational process failures.
FMEA team is composed of 6 people with different special characteristics and occupational experiences. Team approach has brought together a variety of perspectives and experiences. Fig. 4 shows the FMEA team members.

\begin{tabular}{|ccc|}
\hline Name Sumame & Position & Function \\
\hline Analyst 1 & Production Team Leader/Packaging Unit & Team Leader \\
Analyst 2 & Liquid \& Semi Solid Production Specialist & Team Member \\
Analyst 3 & Product Steward & Team Member \\
Analyst 4 & Product Steward & Team Member \\
Analyst 5 & Industrial Engineer \& Intem in the company & Team Member \\
Analyst 6 & Industrial Engineer & Team Member \\
\hline
\end{tabular}

Figure 4. FMEA team of our study

In this paper, solid and liquid products packaging stage is examined with engineers and assessments have been made on possible failures.

\subsection{Identifying risks}

During the study, packaging lines are carefully followed and the potential failures are identified. After careful review, there are 19 failures were found in both blistering and syrup filling lines. While the evaluation of failures, previous documents, quality complaints, factory standards and procedures have been reviewed.

First of all, the system works has been analyzed and decided which sections need improving. Material consumption, filling or blistering, carton packing and line release sections are examined.

After review of manufacturing processes and records, potential failures were determined with the responsible people in this section using by brainstorming method. Purpose is determining the root cause of all situations that could create hazards by detecting.

Table 5. Blistering line risks in pharmaceutical company

\begin{tabular}{|c|c|c|c|c|}
\hline Failures & Process step & Potential failure & Potential effect & $\begin{array}{c}\text { Potential } \\
\text { causes }\end{array}$ \\
\hline BlisteringF1 & Blistering & Leakage in blister & Recall, rework & $\begin{array}{l}\text { Equipment, } \\
\text { human failure }\end{array}$ \\
\hline $\begin{array}{l}\text { BlisteringF2 } \\
\text { BlisteringF3 }\end{array}$ & $\begin{array}{l}\text { Blistering } \\
\text { Blistering }\end{array}$ & $\begin{array}{l}\text { Missing tablet in blister } \\
\text { Mix-up foil of any product }\end{array}$ & $\begin{array}{l}\text { Recall, rework } \\
\text { Recall, rework }\end{array}$ & $\begin{array}{l}\text { Equipment } \\
\text { Human failure }\end{array}$ \\
\hline BlisteringF4 & Blistering & Pinhole in blister & Recall, rework & Human failure \\
\hline BlisteringF5 & $\begin{array}{l}\text { Carton } \\
\text { packing }\end{array}$ & Missing blister and leaflet & $\begin{array}{l}\text { Recall, customer } \\
\text { complaint, repack }\end{array}$ & Equipment \\
\hline BlisteringF6 & $\begin{array}{l}\text { Carton } \\
\text { packing }\end{array}$ & Damaged on the folding box & Customer complaint & Equipment \\
\hline BlisteringF7 & $\begin{array}{l}\text { Carton } \\
\text { packing }\end{array}$ & Wrong label & Customer complaint & Human failure \\
\hline BlisteringF8 & $\begin{array}{l}\text { Material } \\
\text { Consumption }\end{array}$ & Unprinted packaging material & $\begin{array}{l}\text { Packaging material } \\
\text { mix-up, reject }\end{array}$ & Supplier failure \\
\hline BlisteringF9 & $\begin{array}{l}\text { Material } \\
\text { Consumption }\end{array}$ & Contaminated packaging material & $\begin{array}{l}\text { Recall, customer } \\
\text { complaint }\end{array}$ & Human failure \\
\hline
\end{tabular}

Failures syrup and tablets (blistering) were examined for over two lines. The failures can be seen at which process step, its effects and causes are listed as in Table 5 and Table 6 and also Fig. 5 shows fishbone analysis of blistering line failures and Fig. 6 shows fishbone analysis of syrup filling line failures. 


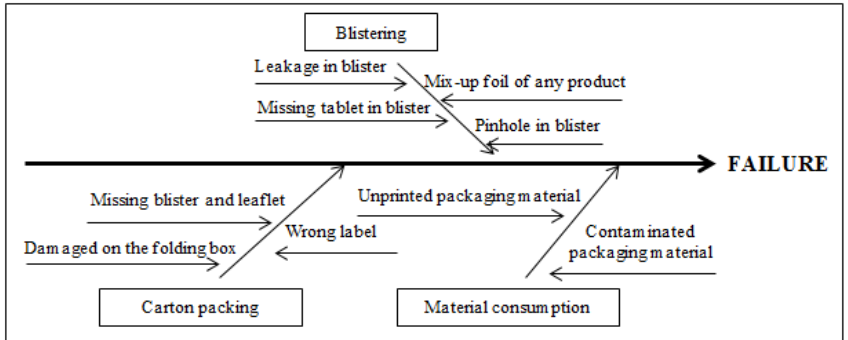

Figure 5. Fishbone analysis of blistering line failures

Table 6. Syrup filling line risks in pharmaceutical company

\begin{tabular}{|c|c|c|c|c|}
\hline Failures & Process step & Potential failure & Potential causes & Potential effects \\
\hline SyrupF1 & Filling & Broken bottles & $\begin{array}{l}\text { Machine failure, supplier } \\
\text { failure }\end{array}$ & $\begin{array}{l}\text { Reject, customer } \\
\text { complaint }\end{array}$ \\
\hline SyrupF2 & Filling & $\begin{array}{l}\text { Wrong filling volume } \\
\text { or mass }\end{array}$ & $\begin{array}{l}\text { Equipment setting, human } \\
\text { failure }\end{array}$ & $\begin{array}{l}\text { Recall, customer } \\
\text { complaint, reject }\end{array}$ \\
\hline SyrupF3 & $\begin{array}{l}\text { Carton } \\
\text { packing }\end{array}$ & Wrong print & Human failure & $\begin{array}{l}\text { Recall, customer } \\
\text { complaint }\end{array}$ \\
\hline SyrupF4 & $\begin{array}{l}\text { Carton } \\
\text { packing }\end{array}$ & $\begin{array}{l}\text { Lack of or missing } \\
\text { variable data }\end{array}$ & $\begin{array}{l}\text { Equipment, failure in } \\
\text { embossing }\end{array}$ & Recall, repack \\
\hline SyrupF5 & $\begin{array}{l}\text { Carton } \\
\text { packing }\end{array}$ & $\begin{array}{l}\text { Missing spoon and } \\
\text { leaflet }\end{array}$ & $\begin{array}{l}\text { Equipment, failure in } \\
\text { sensor }\end{array}$ & $\begin{array}{l}\text { Recall, customer } \\
\text { complaint }\end{array}$ \\
\hline SyrupF6 & $\begin{array}{l}\text { Carton } \\
\text { packing }\end{array}$ & $\begin{array}{l}\text { Shipping case failure } \\
\text { to open }\end{array}$ & Supplier failure & Machines stop \\
\hline SyrupF7 & $\begin{array}{l}\text { Material } \\
\text { consumption }\end{array}$ & Damaged material & $\begin{array}{l}\text { Human failure in } \\
\text { transportation, supplier } \\
\text { failure }\end{array}$ & $\begin{array}{l}\text { Customer } \\
\text { complaint }\end{array}$ \\
\hline SyrupF8 & $\begin{array}{l}\text { Material } \\
\text { consumption }\end{array}$ & $\begin{array}{l}\text { Improper packaging } \\
\text { material }\end{array}$ & Human failure & $\begin{array}{l}\text { Recall, customer } \\
\text { complaint, reject }\end{array}$ \\
\hline SyrupF9 & $\begin{array}{l}\text { Material } \\
\text { consumption }\end{array}$ & $\begin{array}{l}\text { Use of wrong } \\
\text { packaging material }\end{array}$ & Human failure & $\begin{array}{l}\text { Packaging materia } \\
\text { mix-up, reject }\end{array}$ \\
\hline SyrupF10 & Line release & $\begin{array}{l}\text { Mix-up of set-up } \\
\text { material }\end{array}$ & Human failure & $\begin{array}{l}\text { Customer } \\
\text { complaint }\end{array}$ \\
\hline
\end{tabular}

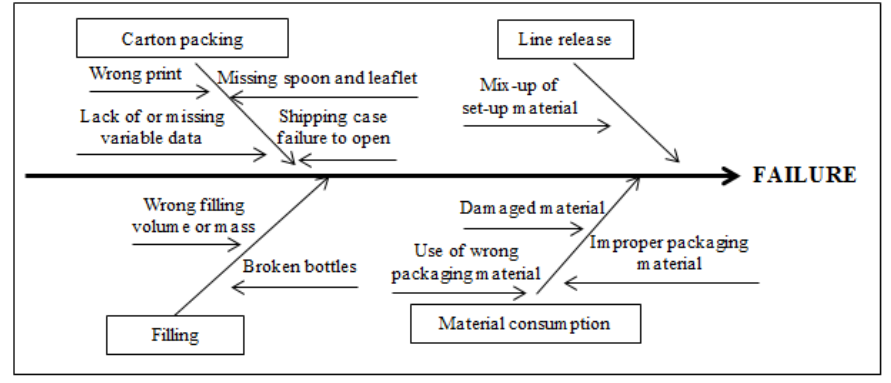

Figure 6. Fishbone analysis of syrup filling line failures

\subsection{Developing fuzzy pairwise comparison matrixes}

In fuzzy prioritization method the AHP method is performed firstly. In fuzzy AHP, the questionnaire can be performed for the comparison of the importance or preference of risk according to others for understanding the importance degree of the risks for each other. Table 7-12 show fuzzy assessment matrixes for occurrence, severity and detection of the risks respectively for two packaging lines (blistering and syrup filling).

Table 7. Fuzzy pairwise comparison matrix for occurrence of risks in blistering line

\begin{tabular}{cccccccccc}
\hline & $B F_{1}$ & $B F_{2}$ & $B F_{3}$ & $B F_{4}$ & $B F_{5}$ & $B F_{6}$ & $B F_{7}$ & $B F_{8}$ & $B F_{9}$ \\
\hline$B F_{1}$ & EI & & SI & SI & & & & SI & SI \\
$B F_{2}$ & VSI & EI & AI & AI & SI & SI & WI & AI & AI \\
$B F_{3}$ & & & EI & WI & & & & WI & WI \\
$B F_{4}$ & & & WI & EI & & & & WI & WI \\
$B F_{5}$ & SI & & VSI & VSI & EI & WI & & VSI & VSI \\
$B F_{6}$ & SI & & VSI & VSI & WI & EI & & VSI & VSI \\
$B F_{7}$ & VSI & WI & AI & AI & SI & SI & EI & AI & AI \\
$B F_{8}$ & & & WI & WI & & & & EI & WI \\
$B F_{9}$ & WI & & WI & WI & & & & WI & EI \\
\hline$W_{\text {OCCURENCE-BFR }}=(0.08,0.21,0.07,0.07,0.11,0.11,0.21,0.07,0.07)^{T}$ & & & & &
\end{tabular}

Table 8. Fuzzy pairwise comparison matrix for severity of risks in blistering line

\begin{tabular}{cccccccccc}
\hline & $B F_{1}$ & $B F_{2}$ & $B F_{3}$ & $B F_{4}$ & $B F_{5}$ & $B F_{6}$ & $B F_{7}$ & $B F_{8}$ & $B F_{9}$ \\
\hline$B F_{1}$ & EI & WI & WI & SI & SI & AI & AI & SI & VSI \\
$B F_{2}$ & WI & EI & WI & SI & SI & AI & AI & SI & VSI \\
$B F_{3}$ & WI & WI & EI & SI & SI & AI & AI & SI & VSI \\
$B F_{4}$ & & & & EI & WI & VSI & VSI & WI & SI \\
$B F_{5}$ & & & & WI & EI & VSI & VSI & WI & SI \\
$B F_{6}$ & & & & & & EI & WI & & \\
$B F_{7}$ & & & & & & WI & EI & & \\
$B F_{8}$ & & & & & WI & VSI & VSI & EI & SI \\
$B F_{9}$ & & & & & SI & SI & & EI \\
\hline$W_{S V I}$
\end{tabular}

$W_{\text {SEVERITY }-B F R}=(0.19,0.19,0.19,0.08,0.08,0.060 .06,0.08,0.07)^{T}$ 
Table 9. Fuzzy pairwise comparison matrix for detection of risks in blistering line

\begin{tabular}{|c|c|c|c|c|c|c|c|c|c|}
\hline & $B F_{1}$ & $B F_{2}$ & $B F_{3}$ & $B F_{4}$ & $B F_{5}$ & $B F_{6}$ & $B F_{7}$ & $B F_{8}$ & $B F_{9}$ \\
\hline$B F_{1}$ & EI & VSI & AI & AI & WI & SI & AI & SI & SI \\
\hline$B F_{2}$ & & EI & SI & SI & & & SI & & \\
\hline$B F_{3}$ & & & EI & WI & & & WI & & \\
\hline$B F_{4}$ & & & WI & EI & & & WI & & \\
\hline$B F_{5}$ & WI & VSI & AI & AI & EI & SI & AI & SI & SI \\
\hline$B F_{6}$ & & SI & VSI & VSI & & EI & VSI & WI & WI \\
\hline$B F_{7}$ & & & WI & WI & & & EI & & \\
\hline$B F_{8}$ & & SI & VSI & VSI & & WI & VSI & EI & WI \\
\hline$B F_{9}$ & & SI & VSI & VSI & & WI & VSI & WI & EI \\
\hline
\end{tabular}

Table 10. Fuzzy pairwise comparison matrix for occurrence of risks in syrup filling line

\begin{tabular}{ccccccccccc}
\hline & $S F_{1}$ & $S F_{2}$ & $S F_{3}$ & $S F_{4}$ & $S F_{5}$ & $S F_{6}$ & $S F_{7}$ & $S F_{8}$ & $S F_{9}$ & $S F_{10}$ \\
\hline$S F_{1}$ & EI & SI & & SI & VSI & SI & & VSI & SI & SI \\
$S F_{2}$ & & EI & & WI & SI & WI & & SI & WI & WI \\
$S F_{3}$ & SI & VSI & EI & VSI & AI & VSI & WI & AI & VSI & VSI \\
$S F_{4}$ & & WI & & EI & SI & WI & & SI & WI & WI \\
$S F_{5}$ & & & & EI & & & WI & & \\
$S F_{6}$ & & WI & & WI & SI & EI & & SI & WI & WI \\
$S F_{7}$ & SI & VSI & WI & VSI & AI & VSI & EI & AI & VSI & VSI \\
$S F_{8}$ & & & & & W & & & EI & & \\
$S F_{9}$ & & WI & & WI & SI & WI & & SI & EI & WI \\
$S F_{10}$ & & WI & & WI & SI & WI & & SI & WI & EI \\
\hline
\end{tabular}

$W_{\text {OCCURENCE-SFR }}=(0.10,0.08,0.19,0.08,0.06,0.08,0.19,0.06,0.08,0.08)^{T}$

Table 11. Fuzzy pairwise comparison matrix for severity of risks in syrup filling line

\begin{tabular}{|c|c|c|c|c|c|c|c|c|c|c|}
\hline & $S F_{1}$ & $S F_{2}$ & $S F_{3}$ & $S_{4}$ & $S F_{5}$ & $S F_{6}$ & $S F_{7}$ & $S F_{8}$ & $S F_{9}$ & $S F_{10}$ \\
\hline$S F_{1}$ & EI & VSI & AI & SI & SI & $\mathrm{AI}$ & SI & WI & WI & SI \\
\hline$S F_{2}$ & & EI & SI & & & SI & & & & \\
\hline$S F_{3}$ & & & EI & & & WI & & & & \\
\hline$S F_{4}$ & & SI & VSI & EI & WI & VSI & WI & & & WI \\
\hline$S F_{5}$ & & SI & VSI & WI & EI & VSI & WI & & & WI \\
\hline$S F_{6}$ & & & WI & & & EI & & & & \\
\hline$S F_{7}$ & & SI & VSI & WI & WI & VSI & EI & & & WI \\
\hline$S F_{8}$ & WI & VSI & AI & SI & SI & AI & SI & EI & WI & SI \\
\hline$S F_{9}$ & WI & VSI & AI & SI & SI & AI & SI & WI & EI & SI \\
\hline$S F_{10}$ & & SI & VSI & WI & WI & VSI & WI & & & EI \\
\hline
\end{tabular}

Table 12. Fuzzy pairwise comparison matrix for detection of risks in syrup filling line

\begin{tabular}{|c|c|c|c|c|c|c|c|c|c|c|}
\hline & $S F_{1}$ & $S F_{2}$ & $S F_{3}$ & $S F_{4}$ & $S F_{5}$ & $S F_{6}$ & $S F_{7}$ & $S F_{8}$ & $S F_{9}$ & $S F_{10}$ \\
\hline$S F_{1}$ & EI & WI & SI & SI & SI & SI & & & SI & WI \\
\hline$S F_{2}$ & WI & EI & SI & SI & SI & SI & & & SI & WI \\
\hline $\mathrm{SF}_{3}$ & & & EI & WI & WI & WI & & & WI & \\
\hline$S F_{4}$ & & & WI & EI & WI & WI & & & WI & \\
\hline$S F_{5}$ & & & WI & WI & EI & WI & & & WI & \\
\hline$S F_{6}$ & & & WI & WI & WI & EI & & & WI & \\
\hline$S F_{7}$ & SI & SI & VSI & VSI & VSI & VSI & EI & & VSI & SI \\
\hline$S F_{8}$ & VSI & VSI & AI & AI & AI & AI & SI & EI & $\mathrm{AI}$ & VSI \\
\hline$S F_{9}$ & & & WI & WI & WI & WI & & & EI & \\
\hline$S F_{10}$ & WI & WI & SI & SI & SI & SI & & & SI & EI \\
\hline
\end{tabular}




\subsection{Computing importance coefficients with fuzzy prioritization method}

After operating fuzzy AHP steps we calculated weight vectors for three dimensions such as occurrence, severity and detection. The calculated importance coefficients in other words weight vectors are shown in Table 13 and Table 14 for three FMEA indicators.

Table 13. Importance coefficients computed by fuzzy prioritization method

\begin{tabular}{cccc}
\hline & $\begin{array}{c}\text { Occurrence / } \\
W_{O-B F R}\end{array}$ & $\begin{array}{c}\text { Severity / } \\
W_{S-B F R}\end{array}$ & $\begin{array}{c}\text { Detection / } \\
W_{D-B F R}\end{array}$ \\
\hline$B F_{1}$ & 0.08 & 0.19 & 0.20 \\
$B F_{2}$ & 0.21 & 0.19 & 0.09 \\
$B F_{3}$ & 0.07 & 0.19 & 0.07 \\
$B F_{4}$ & 0.07 & 0.08 & 0.07 \\
$B F_{5}$ & 0.11 & 0.08 & 0.20 \\
$B F_{6}$ & 0.11 & 0.06 & 0.10 \\
$B F_{7}$ & 0.21 & 0.06 & 0.07 \\
$B F_{8}$ & 0.07 & 0.08 & 0.10 \\
$B F_{9}$ & 0.07 & 0.07 & 0.10 \\
\hline
\end{tabular}

Table 14. Importance coefficients computed by fuzzy prioritization method

\begin{tabular}{cccc}
\hline & $\begin{array}{c}\text { Occurrence / } \\
W_{O-S F R}\end{array}$ & $\begin{array}{c}\text { Severity / } \\
W_{S-S F R}\end{array}$ & $\begin{array}{c}\text { Detection / } \\
W_{D-S F R}\end{array}$ \\
\hline$S F_{1}$ & 0.10 & 0.17 & 0.11 \\
$S F_{2}$ & 0.08 & 0.07 & 0.10 \\
$S F_{3}$ & 0.19 & 0.05 & 0.07 \\
$S F_{4}$ & 0.08 & 0.08 & 0.07 \\
$S F_{5}$ & 0.06 & 0.08 & 0.07 \\
$S F_{6}$ & 0.08 & 0.05 & 0.07 \\
$S F_{7}$ & 0.19 & 0.08 & 0.12 \\
$S F_{8}$ & 0.06 & 0.17 & 0.21 \\
$S F_{9}$ & 0.08 & 0.17 & 0.07 \\
$S F_{10}$ & 0.08 & 0.08 & 0.11 \\
\hline
\end{tabular}

\subsection{Converting importance coefficients into fmea degrees and calculating rpn values}

The importance coefficients which are given in Table 17-18 are converted FMEA degrees. In these conversions Table 5 is used for occurrence, Table 6 is used for severity and Table 7 is used for detection, respectively.

After calculating the degrees of occurrence, severity and detection, the RPN values are computed according to Eq. (1). The calculated FMEA degrees and RPN values are shown in Table 15 and Table 16. Some RPN values shown in these tables are higher than 100 . That's mean we have to suggest proactive and reactive precautions for these risks.

After calculating the number of risk priorities, the failures' percentages weights and cumulative percentages weights were calculated and failures were ordered from bigger to smaller in Table 17 and Table 18.

The possible failures in blistering and syrup filling line are examined and RPN values are formed with Pareto analysis. Identified potential failures and considering of these causes and effects, RPN values are calculated. Pareto analysis is used to separate major and minor causes of the problem from each other with 80-20 rule. This technique helps to identify the top $20 \%$ of causes that needs to be addressed to resolve the $80 \%$ of the problems. Pareto analysis was determined by high-risk failures. Pareto diagram drawn by $80 \%$ limit of the value of the RPN forming failures identified and it proposed reformative actions for these failures. Leakage in blister and improper packaging material are important problems according to Pareto analysis.

Table 15. Computing occurrence, severity, detection degrees and RPN for blistering line

\begin{tabular}{lcccccccc} 
Risks & $\begin{array}{c}\text { Occurrence } \\
\text { coefficient }\end{array}$ & $\begin{array}{c}\text { Occurrence } \\
\text { according } \\
\text { to } \\
\text { coefficient }\end{array}$ & $\begin{array}{c}\text { Occurrence } \\
\text { degree } \\
(\mathrm{O})\end{array}$ & $\begin{array}{c}\text { Severity } \\
\text { coefficient }\end{array}$ & $\begin{array}{c}\text { Severity } \\
\text { degree } \\
(\mathrm{S})\end{array}$ & $\begin{array}{c}\text { Detection } \\
\text { coefficient }\end{array}$ & $\begin{array}{c}\text { Detection } \\
\text { degree } \\
(\mathrm{D})\end{array}$ & RPN \\
\hline $\mathrm{BF}_{1}$ & 0.08 & 0.000066 & 2 & 0.19 & 9 & 0.20 & 9 & $\mathbf{1 6 2}$ \\
$\mathrm{BF}_{2}$ & 0.21 & 0.000173 & 3 & 0.19 & 9 & 0.09 & 4 & $\mathbf{1 0 8}$ \\
$\mathrm{BF}_{3}$ & 0.07 & 0.000058 & 2 & 0.19 & 9 & 0.07 & 3 & 54 \\
$\mathrm{BF}_{4}$ & 0.07 & 0.000058 & 2 & 0.08 & 4 & 0.07 & 3 & 24 \\
$\mathrm{BF}_{5}$ & 0.11 & 0.000091 & 3 & 0.08 & 4 & 0.20 & 9 & $\mathbf{1 0 8}$ \\
$\mathrm{BF}_{6}$ & 0.11 & 0.000091 & 3 & 0.06 & 3 & 0.10 & 5 & 45 \\
$\mathrm{BF}_{7}$ & 0.21 & 0.000173 & 3 & 0.06 & 3 & 0.07 & 3 & 27 \\
$\mathrm{BF}_{8}$ & 0.07 & 0.000058 & 2 & 0.08 & 4 & 0.10 & 5 & 40 \\
$\mathrm{BF}_{9}$ & 0.07 & 0.000058 & 2 & 0.07 & 3 & 0.10 & 5 & 30 \\
\hline
\end{tabular}


Table 16. Computing occurrence, severity, detection degrees and RPN for syrup filling line

\begin{tabular}{ccccccccc}
\hline Risks & $\begin{array}{c}\text { Occurrenc } \\
\mathrm{e} \\
\text { coefficien } \\
\mathrm{t}\end{array}$ & $\begin{array}{c}\text { Occurrenc } \\
\mathrm{e} \\
\text { according } \\
\text { to } \\
\text { coefficient }\end{array}$ & $\begin{array}{c}\text { Occurrenc } \\
\mathrm{e} \\
\text { degree } \\
(\mathrm{O})\end{array}$ & $\begin{array}{c}\text { Severity } \\
\text { coefficien } \\
\mathrm{t}\end{array}$ & $\begin{array}{c}\text { Severit } \\
\mathrm{y} \\
\text { degree } \\
(\mathrm{S})\end{array}$ & $\begin{array}{c}\text { Detection } \\
\text { coefficien } \\
\mathrm{t}\end{array}$ & $\begin{array}{c}\text { Detectio } \\
\mathrm{n} \\
\text { degree } \\
(\mathrm{D})\end{array}$ & $\mathrm{RPN}$ \\
\hline $\mathrm{SF}_{1}$ & 0.10 & 0.0450 & 6 & 0.17 & 10 & 0.11 & 3 & $\mathbf{1 8 0}$ \\
$\mathrm{SF}_{2}$ & 0.08 & 0.0020 & 4 & 0.07 & 4 & 0.10 & 3 & 48 \\
$\mathrm{SF}_{3}$ & 0.19 & 0.0520 & 7 & 0.05 & 3 & 0.07 & 2 & 42 \\
$\mathrm{SF}_{4}$ & 0.08 & 0.0020 & 4 & 0.08 & 5 & 0.07 & 2 & 40 \\
$\mathrm{SF}_{5}$ & 0.06 & 0.0012 & 4 & 0.08 & 5 & 0.07 & 2 & 40 \\
$\mathrm{SF}_{6}$ & 0.08 & 0.0020 & 4 & 0.05 & 3 & 0.07 & 2 & 24 \\
$\mathrm{SF}_{7}$ & 0.19 & 0.0520 & 7 & 0.08 & 5 & 0.12 & 3 & $\mathbf{1 0 5}$ \\
$\mathrm{SF}_{8}$ & 0.06 & 0.0012 & 4 & 0.17 & 10 & 0.21 & 6 & $\mathbf{2 4 0}$ \\
$\mathrm{SF}_{9}$ & 0.08 & 0.0020 & 4 & 0.17 & 10 & 0.07 & 2 & 80 \\
$\mathrm{SF}_{10}$ & 0.08 & 0.0020 & 4 & 0.08 & 5 & 0.11 & 3 & 60 \\
\hline
\end{tabular}

Table 17. The percentages of risks in blistering line

\begin{tabular}{lcccc}
\hline & Potential Failures & RPN & $\begin{array}{c}\text { Percentages } \\
(\%)\end{array}$ & $\begin{array}{c}\text { Cumulative } \\
\text { Percentage }\end{array}$ \\
\hline$B F_{1}$ & Leakage in blister & 162 & 27.0 & 27.0 \\
$B F_{2}$ & Missing tablet in blister & 108 & 18.0 & 45.0 \\
$B F_{5}$ & Missing blister and leaflet & 108 & 18.0 & 63.0 \\
$B F_{3}$ & Mix-up foil of any product & 54 & 9.0 & 72.0 \\
$B F_{6}$ & Damaged on the folding box & 45 & 7.5 & 79.5 \\
$B F_{8}$ & Unprinted packaging material & 40 & 7.0 & 86.5 \\
$B F_{9}$ & Contaminated packaging material & 30 & 5.0 & 91.5 \\
$B F_{7}$ & Wrong label & 27 & 4.5 & 96.0 \\
$B F_{4}$ & Pinhole in blister & 24 & 4.0 & 100.0 \\
\hline \multicolumn{4}{c}{ TOTAL } & 598 \\
\hline
\end{tabular}

Table 18. The percentages of risks in syrup filling line

\begin{tabular}{|c|c|c|c|c|}
\hline & Potential Failures & RPN & $\begin{array}{c}\text { Percentages } \\
(\%)\end{array}$ & $\begin{array}{l}\text { Cumulative } \\
\text { Percentage }\end{array}$ \\
\hline$S F_{8}$ & Improper packaging material & 240 & 27.9 & 27.9 \\
\hline$S F_{1}$ & Broken bottles & 180 & 21.0 & 48.9 \\
\hline$S F_{7}$ & Damaged material & 105 & 12.2 & 61.1 \\
\hline$S F_{9}$ & Use of wrong packaging material & 80 & 9.3 & 70.4 \\
\hline$S F_{10}$ & Mix-up of set-up material & 60 & 7.0 & 77.4 \\
\hline$S F_{2}$ & Wrong filling volume or mass & 48 & 5.6 & 83.0 \\
\hline$S F_{3}$ & Wrong print & 42 & 4.9 & 87.9 \\
\hline$S F_{4}$ & Lack of or missing variable data & 40 & 4.7 & 92.6 \\
\hline$S F_{5}$ & Missing spoon and leaflet & 40 & 4.7 & 97.3 \\
\hline \multirow[t]{2}{*}{$S F_{6}$} & Shipping case failure to open & 24 & 2.7 & 100.0 \\
\hline & TOTAL & 859 & & \\
\hline
\end{tabular}

5.6. Precautions for operational processes of a pharmaceutical company and new rpn

As seen in Fig. 6 and Fig. 7, six of 19 failures' RPN values are higher than 100 . That's mean we have to suggest precautions and try to decrease occurrence, severity and detection degrees of these failures. 


\begin{tabular}{|lccc|}
\hline & Potential Failures & RPN & Process step \\
\hline$B F_{1}$ & Leakage in blister & 162 & Blistering \\
$B F_{2}$ & Missing tablet in blister & 108 & Blistering \\
$B F_{5}$ & Missing blister and leaflet & 108 & Carton packing \\
$B F_{3}$ & Mix-up foil of any product & 54 & Blistering \\
$B F_{6}$ & Damaged on the folding box & 45 & Carton packing \\
$B F_{8}$ & Unprinted packaging material & 40 & Material consumption \\
$B F_{9}$ & Contaminated packaging material & 30 & Material consumption \\
$B F_{7}$ & Wrong label & 27 & Carton packing \\
$B F_{4}$ & Pinhole in blister & 24 & Blistering \\
\hline & TOTAL & 598 & \\
\hline
\end{tabular}

Figure 6. The risk priority number evaluation in blistering line

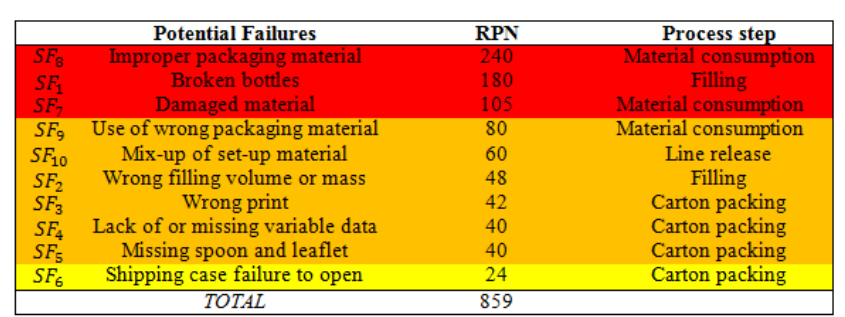

Figure 7. The risk priority number evaluation in syrup filling line

In Fig. 8 and Fig. 9 show precautions and after implementation of these precautions re-determined severity, occurrence, detection values and new RPN for risky 6 failures in blistering and syrup filling lines, respectively.

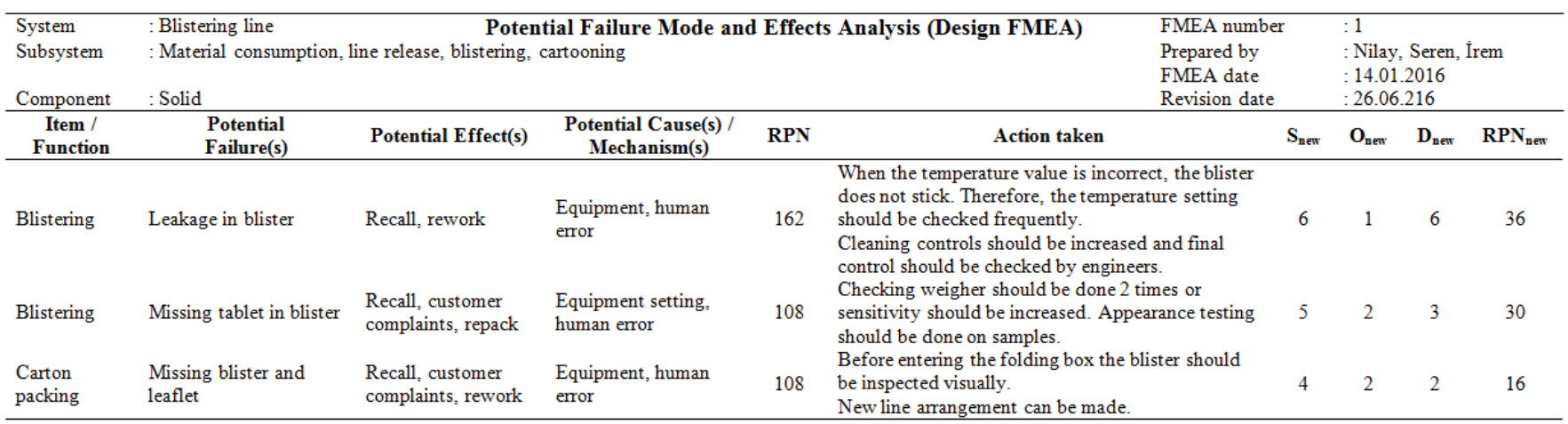

Figure 8. Precautions are taken for three failures in blistering line

\begin{tabular}{|c|c|c|c|c|c|c|c|c|c|c|}
\hline \multirow{4}{*}{$\begin{array}{l}\text { System } \\
\text { Subsystem } \\
\text { Component } \\
\text { Item / } \\
\text { Function }\end{array}$} & \multirow{2}{*}{\multicolumn{5}{|c|}{$\begin{array}{l}\text { : Syrup filling line Potential Failure Mode and Effects Analysis (Design FMEA) } \\
\text { : Material consumption, line release, blistering, carton packing }\end{array}$}} & \multirow{3}{*}{\multicolumn{2}{|c|}{$\begin{array}{l}\text { FMEA number } \\
\text { Prepared by } \\
\text { FMEA date } \\
\text { Revision date }\end{array}$}} & \multirow{3}{*}{\multicolumn{3}{|c|}{$\begin{array}{l}: 2 \\
: \text { Nilay, Seren, İrem } \\
: 14.01 .2016 \\
: 26.06 .216\end{array}$}} \\
\hline & & & & & & & & & & \\
\hline & : Liquid & & & & & & & & & \\
\hline & Potential Failure(s) & Potential Effect(s) & $\begin{array}{c}\text { Potential Cause(s) / } \\
\text { Mechanism(s) }\end{array}$ & RPN & \multicolumn{2}{|l|}{ Action taken } & $\mathrm{S}_{\text {new }}$ & $\mathbf{O}_{\text {new }}$ & $\mathbf{D}_{\text {new }}$ & $\mathrm{RPN}_{\text {new }}$ \\
\hline $\begin{array}{l}\text { Material } \\
\text { consumption }\end{array}$ & $\begin{array}{l}\text { Improper packaging } \\
\text { material }\end{array}$ & $\begin{array}{l}\text { Recall, customer } \\
\text { complaints, reject }\end{array}$ & Human error & 240 & \multirow{2}{*}{\multicolumn{2}{|c|}{$\begin{array}{l}\text { Take action urgently. The company should arrange } \\
\text { technical visits to suppliers in regular intervals and } \\
\text { line control can be done. } \\
\text { Operators should read the barcodes before } \\
\text { bringing on line the packaging material and also } \\
\text { operators should be trained about the quality of the } \\
\text { system. The effectiveness of this training should } \\
\text { be tested. }\end{array}$}} & 4 & 3 & 5 & 60 \\
\hline Filling & Broken bottles & $\begin{array}{l}\text { Reject, customer } \\
\text { complaints }\end{array}$ & $\begin{array}{l}\text { Machine failure, } \\
\text { supplier error }\end{array}$ & 180 & & & 6 & 1 & 3 & 18 \\
\hline $\begin{array}{l}\text { Material } \\
\text { consumption }\end{array}$ & Damaged material & $\begin{array}{l}\text { Customer } \\
\text { complaints }\end{array}$ & $\begin{array}{l}\text { Supplier, human error } \\
\text { in transportation }\end{array}$ & 105 & \multicolumn{2}{|c|}{$\begin{array}{l}\text { The failure is originated from the machine, line } \\
\text { arrangements can be made. The supplier of } \\
\text { sourced warehouse checks should be increased. }\end{array}$} & 4 & 2 & 2 & 16 \\
\hline
\end{tabular}

Figure 9. Precautions are taken for three failures in syrup filling line.

Table 19. Old and new RPN values for risky six failures

\begin{tabular}{lcccc}
\hline & Potential Failures & RPN & New RPN & Changes (\%) \\
\hline$S F_{8}$ & Improper packaging material & 240 & 60 & 75.0 \\
$S F_{1}$ & Broken bottles & 180 & 18 & 90.0 \\
$B F_{1}$ & Leakage in blister & 162 & 36 & 77.8 \\
$B F_{2}$ & Missing tablet in blister & 108 & 30 & 72.2 \\
$B F_{5}$ & Missing blister and leaflet & 108 & 16 & 85.2 \\
$S F_{7}$ & Damaged material & 105 & 16 & 84.8 \\
\hline
\end{tabular}


In this paper, we analyzed our sample pharmaceutical company's risk assessment with fuzzy FMEA technique. In this application failures were identified and listed, their occurrence, severity and detection degrees were calculated by fuzzy prioritization method. Then the precautions were suggested for risky six failures. After implementation of these precautions the new occurrence, severity and detection degrees were calculated by classical FMEA technique. In Table 19 , new RPN values and the changes between old and new RPN's are seen. Also, Fig. 10 shows the comparison of old and new RPN values histogram.

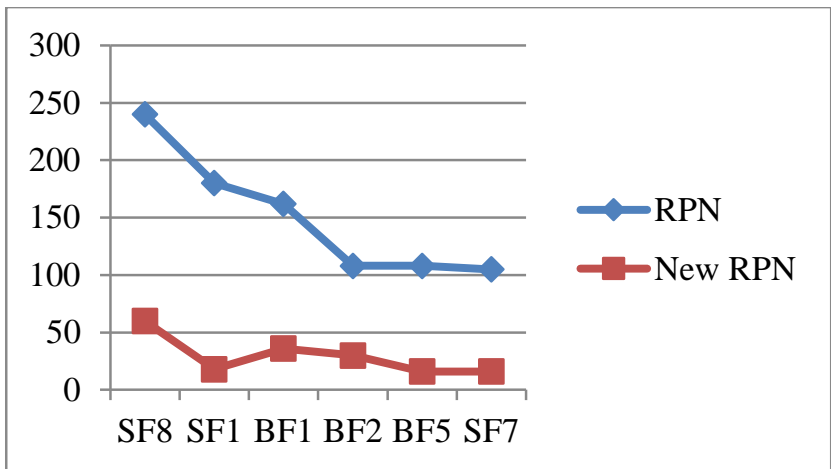

Figure 10. The comparison histogram of old and new RPN values

After our precautions are taken, we decreased our 6 RPN values of the failures. Improper packaging material failure's RPN value was changed from 240 to 60 , broken bottles failure's RPN value was changed from 180 to 18 , leakage in blister failure's RPN value was changed from 162 to 36 , missing tablet in blister failure's RPN value was changed from 108 to 30, missing blister and leaflet failure's RPN value was changed from 108 to 16 and damaged material failure's RPN value was changed from 105 to 16 .

In this way, our 6 failures RPN values are lower than 100 and now the values are $40 \leq \mathrm{RPN} \leq 100$ extra precautions can be taken in the next days.

\section{Conclusions}

In today's advancing technology, risks have to be identified in the design phase of the product for minimizing potential failures. Due to providing quality products for customers protects the companies' high position in the market.

In this paper, we applied FMEA technique with fuzzy prioritization method for a pharmaceutical company. Failures and risks were determined which were seen in blister and syrup filling lines by brainstorming and fishbone analysis in FMEA team. Each line was examined separately. For all potential risks severity, detection and occurrence values were determined. These values were obtained by comparison matrixes with triangular numbers under fuzzy environment. By multiplying FMEA indicators, the risk priority number value was calculated. By using the Pareto analysis, these values were ranked in order of importance and percentage values were found. Pareto analysis was performed separately for blister and syrup filling line. After this analysis some precautions were suggested for 6 risky failures and tried to reduce RPN values of them.

As a result, all risky failures RPN values were reduced in the ratio between $72 \%$ and $90 \%$. This efficiency can be realized by investments to be made on the equipment, employees and supplier.

This paper is the first study due to its solution techniques in sectoral manner such as FMEA with fuzzy prioritization method. Our research paper, will shed light for different implementation of the risk assessment problems in other sectoral fields with similar techniques in future researches.

\section{Conflicts of interest}

The authors declare that there is no conflict of interest regarding the publication of this article.

\section{References}

[1] Carpitella S., Certa A., Izquierdo J. and Fata C.N.L., A combined multi-criteria approach to support FMECA analyses: A real-world case. Reliability Engineering and System Safety, 169 (2018) 394-402.

[2] Kutlu A.C., Ekmekçioğlu M., Fuzzy failure modes and effects analysis by using fuzzy TOPSIS-based fuzzy AHP. Expert Systems with Applications, 39(1) (2012) 61-67.

[3] Fattahi R., Khalilzadeh M., Risk evaluation using a novel hybrid method based on FMEA, extended MULTIMOORA, and AHP methods under fuzzy environment. Safety Science, 102 (2018) 290-300.

[4] Kumru M., Kumru P.Y., Fuzzy FMEA application to improve purchasing process in a public hospital. Applied Soft Computing, 13 (2013) 721-733.

[5] Mandal S., Maiti J., Risk analysis using FMEA: Fuzzy similarity value and possibility theory based approach. Expert Systems with Applications, 41 (2014) 3527-3537. 
[6] Chen Z., Wu X. and Qin J., Risk assessment of an oxygen-enhanced combustor using a structural model based on the FMEA and fuzzy fault tree. Journal of Loss Prevention in the Process Industries, 32 (2014) 349-357.

[7] Chanamool N., Naenna T., Fuzzy FMEA application to improve decision-making process in an emergency department. Applied Soft Computing, 43 (2016) 441-453.

[8] Dağsuyu C., Göçmen E., Narlı M. and Kokangül A., Classical and fuzzy FMEA risk analysis in a sterilization unit. Computers \& Industrial Engineering, 101 (2016) 286-294.

[9] Tooranloo H.S., Ayatollah A.S., A model for failure mode and effects analysis based on intuitionistic fuzzy approach. Applied Soft Computing, 49 (2016) 238-247.

[10] Adar E., İnce M., Karatop B. and Bilgili M.S., The risk analysis by failure mode and effect analysis (FMEA) and fuzzy-FMEA of supercritical water gasification system used in the sewage sludge treatment. Journal of Environmental Chemical Engineering, 5 (2017) 1261-1268.

[11] Lv Y., Liang Y., Application of FMEA based on fuzzy multi-criteria decision-making for HVAC in a pharmaceutical plant. Journal of Chemical and Pharmaceutical Research, 6(6) (2014) 1116-1123.

[12] Bhattacharya J., Quality risk management Understanding and control the risk in pharmaceutical manufacturing industry. International Journal of Pharmaceutical Science Invention, 4(1) (2015) 29-41.

[13] Hajimolaali M., Asl A.A., Quality risk assessment production of beta lactams by FMEA model and fuzzy theory method. General Medicine: Open Access, 4(1) (2016).

[14] Su C.T., Chou C.J., Hung S.H. and Wang P.C., Adopting the healthcare failure mode and effect analysis to improve the blood transfusion processes. International Journal of Industrial Engineering, 19(8) (2012) 320-329.

[15] Liu H.C., Liu L., Liu N. and Mao L.X., Risk evaluation in failure mode and effects analysis with extended VIKOR method under fuzzy environment. Expert Systems with Applications, 39 (2012) 12926-12934.

[16] Liu H.C., You X.J., You X.Y. and Shan M.M., A novel approach for failure mode and effects analysis using combination weighting and fuzzy VIKOR method. Applied Soft Computing, 28 (2015) 579-588.

[17] Mohsen O., Fereshteh N., An extended VIKOR method based on entropy measure for the failure modes risk assessment - A case study of the geothermal power plant (GPP). Safety Science, 92 (2017) 160-172.

[18] Mikhailov L., Tsvetinov P., Evaluation of services using a Fuzzy Analytic Hierarchy Process. Applied Soft Computing, 5(1) (2004) 23-33.

[19] Özfirat P.M., A new risk analysis methodology integrating fuzzy prioritization method and failure modes and effects analysis. Journal of the Faculty of Engineering and Architecture of Gazi University, 29(4) (2014) 755-768.

[20] Rahimi S.A., Jamshidi A., Ait-Kadi D., Ruiz A. and Rebaiaia M.L., Prioritization of failures in radiation therapy delivery. IFAC-PapersOnLin, 49(12) (2016) 1898-1903.

[21] http://www.ispe.org/gmp-resources, Arrival date: 20.11.2017.

[22] Wessiani N.A., Sarwoko S.O., Risk analysis of poultry feed production using fuzzy FMEA. Procedia Manufacturing, 4 (2015) 270-281.

[23] Spreafico C., Russo D. and Rizzi C., A state-ofthe-art review of FMEA/FMECA including patents. Computer Science Review, 25 (2017) 19-28.

[24] Villarini M., Cesarotti V., Alfonsi L. and Introna V., Optimization of photovoltaic maintenance plan by means of a FMEA approach based on real data. Energy Conversion and Management, 152 (2017) 1-12.

[25] Tague, N.R., The Quality Toolbox, 2th ed. United States of America: ASQ Quality Press Milwakee, Wisconsin, 2005; 35-54.

[26] Yazdi M., Daneshvar S. and Setareh H., An extension to Fuzzy Developed Failure Mode and Effects Analysis (FDFMEA) application for aircraft landing system. Safety Science, 98 (2017) 113-123.

[27] Ilbahar E., Karaşan A., Cebi S. and Kahraman S., A novel approach to risk assessment for occupational health and safety using Pythagorean fuzzy AHP \& fuzzy inference system. Safety Science, 103 (2018) 124-136.

[28] Chang K.H., Evaluate the orderings of risk for failure problems using a more general RPN methodology. Microelectronics Reliability, 49 (2009) 1586-1596.

[29] Hassan A., Siadat A., Dantan J.Y. and Martin P., Conceptual process planning - an improvement approach using QFD, FMEA, and ABC methods. Robotics and Computer-Integrated Manufacturing, 26 (2010) 392-401.

[30] Feili H.R., Akar N., Lotfizadeh H., Bairampour N. and Nasiri S., Risk analysis of geothermal power plants using Failure Modes and Effects 
Analysis (FMEA) technique. Energy Conversion and Management, 72 (2013) 69-76.

[31] Wang Y.M., Chin K.S., Poon G.K.K. and Yang J.B., Risk evaluation in failure mode and effects analysis using fuzzy weighted geometric mean. Expert Systems with Applications, 36 (2009) 1195-1207.

[32] Xiao N., Huang H.Z., Li Y., He L. and Jin T., Multiple failure modes analysis and weighted risk priority number evaluation in FMEA. Engineering Failure Analysis, 18 (2011) 11621170.

[33] Chang D.Y., Applications of the extent analysis method on fuzzy AHP. European Journal of Operational Research, 95 (1996) 649-655.

[34] Wang Y.M., Chin K.S., Fuzzy analytic hierarchy process: A logarithmic fuzzy preference programming methodology. International Journal of Approximate Reasoning, 52(4) (2011) 541-553.

[35] Constantinescu A., Sum-fuzzy implementation of a choice function using artificial learning procedure with fixed fraction. Applications of Mathematics, 52(4) (2007) 321-326.

[36] Yu C.S., A GP-AHP method for solving group decision-making fuzzy AHP problems. Computers \& Operations Research, 29(14) (2002) 1969-2001.

[37] Bisso C.S., Samanez C.P., Efficient determination of heliports in the city of Rio De Janerio for the Olympic games and world cup: A fuzzy logic approach. International Journal of Industrial Engineering, 21(1) (2014) 33-44.

[38] Yayla A.Y., Yıldız A., Fuzzy Analytic Network Process based multi criteria decision making methodology for a family automobile purchasing decision. South African Journal of Industrial Engineering, 24(2) (2013) 1-14. 